\title{
The effects of amantadine on lung tissue in lower limb ischemia/reperfusion injury model in rats
}

\author{
Amantadinin alt ekstremite iskemi/reperfüzyon sıçan modelinde akciğer dokusu üzerindeki etkileri
}

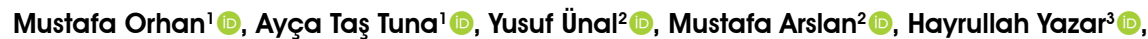 \\ Şaban Cem Sezen ${ }^{4}$, Sezen Irmak Gözükara ${ }^{5}$, Onur Palabıyık ${ }^{\circledR}$ \\ Institution where the research was done: \\ Gazi University, Faculty of Medicine, Ankara, Turkey \\ Author Affiliations: \\ 'Department of Anesthesiology of Reanimation, Sakarya University, Faculty of Medicine, Sakarya, Turkey \\ 2Department of Anesthesiology of Reanimation, Gazi University, Faculty of Medicine, Ankara, Turkey \\ ${ }^{3}$ Department of Biochemistry, Sakarya University, Faculty of Medicine, Sakarya, Turkey \\ ${ }^{4}$ Department of Histology and Embryology, Kırıkale University, Faculty of Medicine, Kırıkkale, Turkey \\ ${ }^{5}$ Biochemistry Clinic, Sakarya University, Training and Research Hospital, Sakarya, Turkey
}

\section{ABSTRACT}

Background: This study aims to evaluate the effect of amantadine on lung tissue of after lower limb ischemia/reperfusion injury in rats.

Methods: A total of 24 Wistar rats were divided into four equal groups including six rats in each: sham group (Group S), amantadine group (Group A), ischemia/reperfusion group (Group I/R), and ischemia/reperfusion + amantadine group (Group I/R-A). All groups underwent a midline abdominal incision. In Groups I/R and I/R-A, the infrarenal abdominal aorta was clamped for $120 \mathrm{~min}$ and, then, reperfused for $120 \mathrm{~min}$ after removal of the clamp. Amantadine hydrochloride $45 \mathrm{mg} / \mathrm{kg}$ was administered intraperitoneally to the rats of Groups A and Group I/R-A 15 min before surgery. At the end of reperfusion period ( $240 \mathrm{~min})$, all rats were sacrificed, and their lung tissues were obtained. Lung tissue catalase and superoxide dismutase activities and glutathione S-transferase and malondialdehyde levels were analyzed. Lung tissues were examined histopathologically.

Results: Catalase activity was lower in Groups A, I/R, and I/R-A compared to Group S. Superoxide dismutase activity was higher in Group I/R than Group S. Superoxide dismutase activity in Groups I/R-A and A decreased, compared to Groups $S$ and I/R. Glutathione S-transferase levels decreased in Groups I/R and A, compared to Group S. Glutathione S-transferase levels in Group I/R-A were higher than Groups I/R and A. The highest level of malondialdehyde was found in Group I/R and the lowest level was found in Group I/R-A. According to histopathological examination, infiltration scores were significantly lower in Group $\mathrm{S}$ than Groups I/R and I/R-A ( $\mathrm{p}=0.009$ and $\mathrm{p}=0.011$, respectively). The alveolar wall thickening scores in Group $\mathrm{I} / \mathrm{R}$ were also significantly higher than Groups S and Group A ( $\mathrm{p}=0.001$ and $\mathrm{p}=0.001$, respectively).

Conclusion: Lung tissue can be affected histopathologically by ischemia/ reperfusion injury and this injury can be reversed by amantadine administration.

Keywords: Amantadine, ischemia/reperfusion, lower limb, lung.
$\ddot{O} Z$

Amaç: Bu çalışmada, sıçanlarda alt ekstremite iskemi/reperfüzyon hasarından sonra amantadinin akciğer dokusu üzerindeki etkisi araştırıldı.

Calısma planı: Toplam 24 adet Wistar cinsi sıçan her grupta altı sıçan olacak şekilde dört eşit gruba ayrıldı: Sham grubu (Grup S), amantadin grubu (Grup A), iskemi/reperfüzyon grubu (Grup I/R) ve $\mathrm{I} / \mathrm{R}+$ amantadin grubu (Grup I/R-A). Tüm gruplara orta abdominal insizyon uyguland1. Grup I/R ve I/R-A'da infrarenal abdominal aorta $120 \mathrm{dk}$. süreyle klemplendi ve ardından klemp kaldırılarak $120 \mathrm{dk}$. süreyle reperfüze edildi. Grup A ve I/R-A'daki sıçanlara $45 \mathrm{mg} / \mathrm{kg}$ amantadin hidroklorür cerrahiden $15 \mathrm{dk}$. önce intraperitoneal olarak uygulandı. Reperfüzyon periyodu sonunda ( $240 \mathrm{dk}$.) tüm sıçanlar sakrifiye edildi ve akciğer dokuları alındı. Akciğer dokusunda katalaz ve süperoksit dismutaz aktiviteleri ve glutatyon S-transferaz ve malondialdehit düzeyleri çalışıldı. Akciğer dokuları histopatolojik olarak incelendi.

Bulgular: Katalaz aktivitesi Grup A, I/R ve I/R-A'da, Grup S'ye kıyasla daha düşüktü. Süperoksit dismutaz aktivitesi Grup I/R'de, Grup S'ye kıyasla daha yüksekti. Grup I/R-A ve A'da, Grup S ve I/R'ye kıyasla, süperoksit dismutaz aktivitesi azaldı. Glutatyon S-transferaz düzeyleri Grup I/R ve A'da, Grup S'ye kıyasla azaldı. Glutatyon S-transferaz düzeyleri, Grup I/RA'da, Grup I/R ve A'ya kıyasla daha yüksekti. Malondialdehit düzeyleri, Grup I/R'de en yüksek ve Grup IR-A'da en düşük izlendi. Histopatolojik incelemeye göre, Grup S'de infiltrasyon skoru Grup I/R ve Grup I/R-A'ya kıyasla, anlamlı düzeyde daha düsüktü (sırasıyla. $\mathrm{p}=0.009$ ve $\mathrm{p}=0.011$ ). Grup I/R'de alveol duvar kalınlaşması skoru, Grup S ve Grup A'ya kıyasla, anlamlı düzeyde yüksekti (sırasıyla, $\mathrm{p}=0.001$ ve $\mathrm{p}=0.001$ ).

Sonuç: Akciğer dokusu iskemi/reperfüzyon hasarından etkilenebilir ve bu hasar amantadin kullanımı ile geri döndürülebilir.

Anahtar sözcükler: Amantadin, iskemi/reperfüzyon, alt ekstremite, akciğer.

Received: April 22, 2020 Accepted: June 04, 2020 Published online: January 13, 2021

Correspondence: Mustafa Arslan, MD. Gazi Üniversitesi Tıp Fakültesi Anesteziyoloji ve Reanimasyon Anabilim Dalı, 06560 Yenimahalle, Ankara, Türkiye. Tel: +90 312 - 2025313 e-mail: mustarslan@gmail.com 
Ischemia is the lack of oxygen caused by insufficient perfusion of organs and tissues due to decreased or complete ablation of arterial or venous blood flow. Ischemia leads to cell death resulting from the depletion of cellular energy stores and the accumulation of toxic metabolites. In the ischemic period, several metabolic and structural changes occur in the cell. Cellular oxidative phosphorylation and high-energy phosphate synthesis, such as adenosine triphosphate and phosphocreatine, are reduced by discontinuation of blood flow to the tissue ${ }^{[1]}$ Ischemic tissue requires blood circulation again for both self-renewal of cells and removal of accumulated toxic substances. However, reperfusion of the ischemic tissue causes more severe injury than tissue injury caused by ischemia, which is called ischemia/reperfusion (I/R) injury. ${ }^{[2]}$ This injury is a pathological condition which continues with a sterile inflammatory response in which neutrophils and free oxygen radicals play a role with insufficient oxygen presentation..$^{[3-6]}$

Lower limb I/R injury occurs, particularly in aortic surgery by temporarily clamping the aorta and by acute or double-sided acute femoral artery occlusion. After $\mathrm{I} / \mathrm{R}$, local injury occurs in the ischemic area and injury to distant organs outside the ischemic area may also occur. The lung is the target organ in distant organ injury. ${ }^{[7-9]}$

$\mathrm{N}$-methyl D-aspartate (NMDA) receptor is a member of the glutamatergic receptor types. ${ }^{[10,11]}$ The NMDA antagonists have been shown to have protective effects against $I / R$ injury in various organs and tissues by increasing antioxidant activity and reducing oxidative effects. ${ }^{[12]}$ Amantadine, is a NMDA receptor antagonist, has direct and indirect glutaminergic and dopaminergic signaling effects. ${ }^{[12-14]}$ Therefore, in the current study, we aimed to investigate the effect of amantadine, an NMDA antagonist, on lung tissue following lower limb I/R injury in rats.

\section{MATERIALS AND METHODS}

This experimental study was conducted at Gazi University Animal Experiments Laboratory on $20^{\text {th }}$ June 2017. The study protocol was approved by the Animal Research Committee of Gazi University, Ankara, Turkey. All animals were maintained in accordance with the recommendations of the National Institutes of Health Guidelines for the Care and Use of Laboratory Animals.

A total of 24 adult male Wistar rats (10-12 week-old, weighing 250 to $330 \mathrm{~g}$ ) were used in the study. The rats were housed in a 12-h luminous, 12-h dark environment, until the initiation of the study. The subjects were examined in a light- and temperaturestandardized environment. Animals did not undergo fluid and food restriction and were fed with standard rat food (pellet feed).

The rats were randomly divided into four equal groups: sham group (Group $S, n=6$ ), the amantadine group (Group $\mathrm{A}, \mathrm{n}=6$ ), the $\mathrm{I} / \mathrm{R}$ group (Group $\mathrm{I} / \mathrm{R}$, $\mathrm{n}=6$ ), and the $\mathrm{I} / \mathrm{R}+$ amantadine group (Group I/R-A, $\mathrm{n}=6$ ). In Groups $\mathrm{A}$ and I/R-A, amantadine $45 \mathrm{mg} / \mathrm{kg}$ (amantadine hydrochloride, A1260-5G, Sigma-Aldrich, St. Louis, USA) was administered intraperitoneally at the same time as anesthetic drugs. A total of $15 \mathrm{~min}$ after the anesthesia induction, surgical procedure was performed.

\section{Experimental procedure}

The abdominal areas of the rats whose weights were measured before anesthesia were shaved before the surgical incision. For anesthesia induction, all rats were administered ketamine $100 \mathrm{mg} / \mathrm{kg}$ (Ketalar $1 \mathrm{~mL}$ : $50 \mathrm{mg}$, Pfizer, Istanbul, Turkey) and xylazine $15 \mathrm{mg} / \mathrm{kg}$ (Xylazine bio 2\% Biovet, Czech Republic) intraperitoneally, and atropine $0.01 \mathrm{mg}$ (Atropine Sulfate $0.5 \mathrm{mg} / \mathrm{mL}$, Biofarma, Istanbul, Turkey) intramuscularly. A heater blanket was used to prevent heat loss and to avoid hypothermia and a rectal thermometer was used for heat monitoring. As the criterion for adequate anesthesia, unresponsiveness to painful stimuli was achieved and, then, tail vein cannulation was performed with a 24-gauge intravenous cannula (R-ES Neo IV, Izmir, Turkey) to ensure hydration. Anesthesia was maintained with an intermittent ketamine and xylazine injection.

In Groups $\mathrm{S}$ and $\mathrm{A}$, a mid-abdominal incision was performed, but no I/R was applied. In Groups I/R and I/R-A, a mid-abdominal incision was performed. After removal of intestines from the surgical field, the infrarenal abdominal aorta was explored, and aorta was clamped by an atraumatic vascular clamp. The clamp was removed after $120 \mathrm{~min}$, and reperfusion was performed for $120 \mathrm{~min}$. Ischemia and reperfusion times of lower limb were performed according to the literature ${ }^{[15]}$ At the end of reperfusion period (240 min), all rats were euthanized for blood and organ sampling.

\section{Biochemical investigations of rat lung tissues}

The lung tissues were collected and stored at $-80^{\circ} \mathrm{C}$. The lung samples were separated into small pieces by removing fat and connective tissues on ice. The samples were weighed and placed in glass tubes containing a cold phosphate buffer $(\mathrm{pH} \mathrm{7.4,}$ $50 \mathrm{mmol} / \mathrm{L}$ ) with a final concentration of $100 \mathrm{mg}$ tissue $/ \mathrm{mL}$. A homogenization process was performed 
on ice homogenizer (ISOLAB, Laborgerate $\mathrm{GmbH}$, Germany), and an ISOLAB homogenization device was used. The obtained homogenate was separated from the debris and other particles by centrifugation at $10,000 \mathrm{~g}, 4^{\circ} \mathrm{C}$, for $10 \mathrm{~min}$. All parameters were studied from the supernatants obtained after centrifugation.

The lung tissue catalase (CAT) and superoxide dismutase (SOD) enzyme activities, and glutathione-S-transferase (GST) levels were measured by enzyme-linked immunosorbent assay (ELISA; Elabscience Biotechnology Co. Ltd., Wuhan, China). The coefficient of measurement within the kit was $<10 \%$. Measurements were made on the automated ELISA analyzer (Triturus, Grifols, Spain), following the manufacturer's protocols. The results were multiplied by the dilution factor, and the results were calculated. Malondialdehyde (MDA) levels were determined to examine the lipid peroxidation status. The MDA levels were also measured and calculated by the same methods.

\section{Histopathological examination}

Histopathological evaluation was performed at Kirikkkale University, Medical Faculty, Histology and Embryology Department. For histopathological examination, lung tissue samples were kept at $+4^{\circ} \mathrm{C}$ in $10 \%$ formaldehyde solution. Tissues were stained with hematoxylin-eosin (H-E) and examined under light microscopy and findings were scored using a scoring system. ${ }^{[16]}$ Pulmonary injury was graded into four categories as follows: Grade 0, no diagnostic change;
Grade 1, mild neutrophil leukocyte infiltrations and mild to moderate interstitial congestion; Grade 2, moderate neutrophil leukocyte infiltrations, perivascular edema formation, and partial destruction of pulmonary architecture; and Grade 3, dense neutrophil leukocyte infiltration and complete destruction of the pulmonary architecture.

\section{Statistical analysis}

Statistical analysis was performed using the IBM SPSS version 23.0 software (IBM Corp., Armonk, NY, USA). Data were expressed in median (min-max) values for the numerical variables. The KruskalWallis test was used for intergroup data comparisons. The Bonferroni-corrected Mann-Whitney U test was used to examine which group differs from the other. A $p$ value of $<0.05$ was considered statistically significant.

\section{RESULTS}

The CAT, SOD activities and GST and MDA levels of four groups are shown in Table 1. The CAT activity decreased in Groups A, I/R, and I/R-A compared to Group S. The CAT activity in Group I/R-A was lower than Groups S, A, and I/R. However, the difference in the CAT activity was not statistically significant among the groups $(\mathrm{p}=0.064)$. The SOD activity of the lung tissue was higher in Group I/R than Group S. The SOD activity in Groups I/R-A and A decreased, compared to Groups $S$ and I/R. However, the difference in the SOD activity was not statistically

Table 1. Oxidative status of lung tissue

\begin{tabular}{|c|c|c|c|c|c|c|c|c|c|}
\hline & \multicolumn{2}{|c|}{ Group $S(n=6)$} & \multicolumn{2}{|c|}{ Group A $(n=6)$} & \multicolumn{2}{|c|}{ Group I/R (n=6) } & \multicolumn{2}{|c|}{ Group I/R-A $(n=6)$} & \multirow[b]{2}{*}{$p$} \\
\hline & Median & Min-Max & Median & Min-Max & Median & Min-Max & Median & Min-Max & \\
\hline CAT (pg/mg) & 4.84 & $3.78-5.63$ & 4.45 & $3.46-4.80$ & 4.66 & $3.89-4.81$ & 3.68 & $3.55-4.57$ & 0.064 \\
\hline $\mathrm{SOD}(\mathrm{pg} / \mathrm{mg})$ & 3.06 & $2.10-3.40$ & 2.68 & $2.12-2.90$ & 3.22 & $2.35-4.61$ & 2.18 & $1.70-2.92$ & 0.052 \\
\hline GST (pg/mg) & 25.05 & $21.00-27.41$ & 22.56 & $20.47-24.00$ & 22.64 & $19.66-26.54$ & 25.66 & $23.90-28.00$ & 0.090 \\
\hline MDA (ng/mg) & 2.90 & $2.71-3.14$ & 3.01 & $2.68-3.47$ & 3.11 & $2.37-3.50$ & 2.49 & $2.36-3.84$ & 0.193 \\
\hline
\end{tabular}

Min: Minimum; Max: Maximum; CAT: Catalase; SOD: Superoxide dismutase; GST: Glutathione-S-transferase; MDA: Malondialdehyde.

Table 2. Alveolar wall thickening and infiltration scores

\begin{tabular}{|c|c|c|c|c|c|c|c|c|c|}
\hline & \multicolumn{2}{|c|}{ Group $S(n=6)$} & \multicolumn{2}{|c|}{ Group A $(n=6)$} & \multicolumn{2}{|c|}{ Group I/R $(n=6)$} & \multicolumn{2}{|c|}{ Group I/R-A $(n=6)$} & \multirow[b]{2}{*}{$p$} \\
\hline & Median & Min-Max & Median & Min-Max & Median & Min-Max & Median & $\operatorname{Min}-\operatorname{Max}$ & \\
\hline Infiltration scores & 0.00 & $0-1$ & 0.50 & $0-1$ & 1.00 & $1-3 *$ & 1.00 & $1-2 *$ & 0.010 \\
\hline Alveolar wall thickening & 0.00 & $0-1 \dagger$ & 0.00 & $0-1 \dagger$ & 2.50 & $1-3$ & 1.00 & $1-2$ & 0.001 \\
\hline
\end{tabular}

Min: Minimum; Max: Maximum; * $\mathrm{p}<0.05$; compared to Group $\mathrm{S} ; \dagger \mathrm{p}<0.05$; compared to Group I/R. 

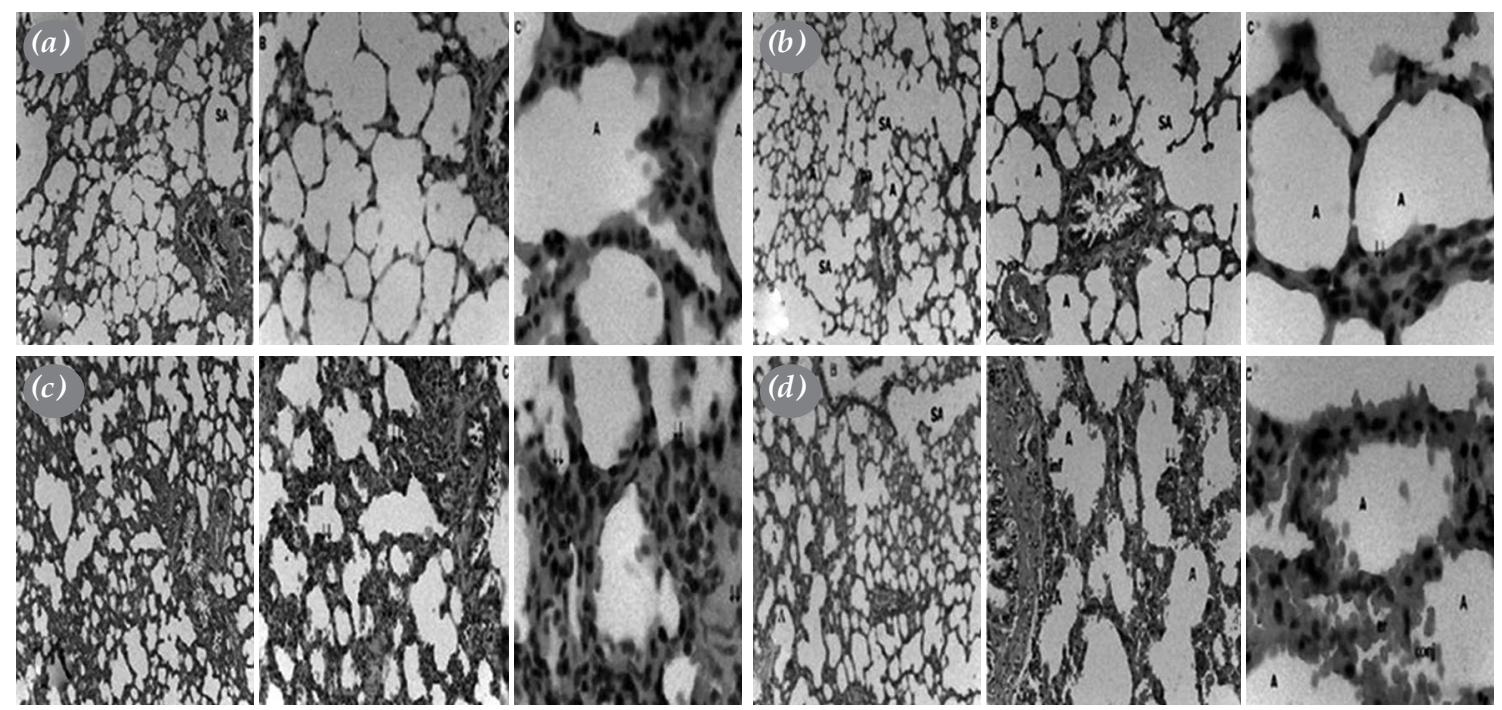

Figure 1. Pulmonary tissue preparations, hematoxylin-eosin $(\times 40 ; \times 100 ; \times 400)$ : (a) Normal lung tissue parenchyma in Group S; (b) Neutrophil infiltration in lung tissue in Group A; (c) Intense neutrophil infiltration and severe increase in alveolar wall thickness in Group I/R; (d) Slight capillary congestion, neutrophil infiltration and slight increase in alveolar wall thickness in Group I/R-A.

significant among the groups $(\mathrm{p}=0.090)$. The GST levels of the lung tissue decreased in Groups I/R and A, compared to Group S. The GST levels in Group I/R-A were higher than Groups I/R and A. However, the GST levels were not statistically significant among the groups $(p=0.052)$. In addition, there were no significant differences in the lung tissue MDA levels among the groups $(p=0.193)$. The highest and lowest level of MDA was found in Group I/R and Group I/R-A, respectively.

As shown in Table 2, lung tissue neutrophil/ lymphocyte infiltration score levels were significantly lower in Group S than Groups I/R and I/R-A ( $\mathrm{p}=0.009$ and $\mathrm{p}=0.011$, respectively). The lung tissue alveolar wall thickening scores were significantly higher in Group I/R than Groups S and A ( $\mathrm{p}=0.001$ and $\mathrm{p}=0.001$, respectively). In Groups $\mathrm{A}$ and $\mathrm{S}$, the results were similar ( $p>0.05$ ). Additionally, the lung tissue alveolar wall thickening scores in Group I/R-A was lower than Group $\mathrm{I} / \mathrm{R}$, although it did not reach statistical significance $(\mathrm{p}>0.05)$.

The histopathological changes of lung tissue are shown in Figure 1. The H-E-stained lung sections of Group $\mathrm{S}$ showed a normal alveolar histological structure. No infiltration was shown, and alveolar wall thickness was normal (Figure 1a). However, there was neutrophil infiltration in the lung sections of Group A (Figure 1b). On the other hand, Group I/R showed some structural changes. Intense neutrophil infiltrations were shown, and alveolar wall thickness increased severely. In addition, there were macrophage and erythrocyte accumulation and edema in some parts of bronchioles and alveolar lumens. Hyperemia, bleeding, and inflammatory cell infiltration in capillaries in the interalveolar septa were observed (Figure 1c). In Group I/R-A, hyperemia, hemorrhage, edema, inflammatory cell infiltration, and partial enlargement in the interalveolar septum were observed (Figure 1d). However, those findings were quite mild in terms of general appearance, compared to Group I/R.

\section{DISCUSSION}

In this study, we evaluated that the histopathological changes in the lung tissue as a distant organ, after the lower limb I/R injury can be limited by amantadine before I/R injury.

The protective effects of NMDA antagonists on lung tissue have been shown in previous studies. ${ }^{[17,18]} \mathrm{In}$ a study investigating the effects of dexmedetomidineketamine combination on ventilator-associated lung injury in endotoxemic rats, the combination of dexmedetomidine-ketamine has been shown to have protective effects on ventilator-associated lung injury and reduce the degree of inflammation. ${ }^{[17]}$ In the literature, however, there is no study available regarding the effects of amantadine on $I / R$ injury. Nevertheless, it has been reported that amantadine decreases oxidative stress in abnormal glutamatergic synaptic transmission of corticosterone-induced 
CA3-CA1 pathway in hippocampal sections in rats, possibly related to the mechanism of neuroprotective effect of amantadine, and it is formed by regulating antioxidant SOD and CAT activities. ${ }^{[19]}$ Some authors suggested that amantadine exerts its effect by reducing $\mathrm{Ca}^{+}$influx into the cell and prevents apoptosis. ${ }^{[19]}$ Furthermore, recent studies have shown how amantadine has been used extensively in their clinical practice of patients with severe traumatic brain injury. ${ }^{[20]}$ In another study in rats with traumatic brain injury, amantadine had a potential value in antidepression treatment by using a dose of 45 or $135 \mathrm{mg} / \mathrm{kg} /$ day. ${ }^{[21]}$ According to this study, we used $45 \mathrm{mg} / \mathrm{kg}$ dose of amantadine to evaluate whether it had a protective effect against I/R injury.

The antioxidant enzyme group, oxidoreductases, represents one of the most important free radical scavenging systems and plays a cell-protective role beyond the antioxidant function. The CAT is one of these antioxidant enzymes. In experimental I/R injury studies, the CAT activity in tissue and serum samples decreased after I/R, compared to control groups, and this reduction was caused by oxidant mechanisms. ${ }^{[19,22]}$ In contrast, other studies showed that CAT activity in tissue and serum samples increased after I/R injury, compared to control groups, and this rising was due to the elimination of hydrogen peroxide caused by elevated SOD activity. ${ }^{[23,24]}$ In our study, the CAT level was decreased after I/R compared to the control group and the CAT activity with amantadine was further decreased. However, we observed no statistically significant difference among the groups in terms of CAT enzyme activity.

Glutathione-S-transferase catalyzes the conjugation of various endogenous and exogenous compounds with glutathion. Glutathion is the most important antioxidant compound in the cell that protects cells from oxidant injury. ${ }^{[25]}$ El-Sayyad et al. ${ }^{[26]}$ reported that GST level decreased after I/R and increased in liver tissue, when mangiferin was administered in intestinal I/R injury in rats. Similar to this study, we observed that GST level of the lung tissue decreased after lower limb I/R injury and increased after amantadine administration. The increase in the GST level suggests that amantadine may have protective effects in I/R. However, GST levels among the groups were not statistically significant.

Antioxidant enzymes play an important role in the removal of free oxygen radicals. The SOD, one of these enzymes, exerts its antioxidant effect by catalyzing the conversion of superoxide to hydrogen peroxide. According to some experimental I/R injury studies, the SOD activity in tissue and serum samples decreased and this reduction might be due to predominance of oxidant mechanisms. ${ }^{[27-29]}$ In contrast, in other studies, the SOD activity increased in tissue and serum samples after $I / R$ and this increase was due to oxidative stress suppression response. ${ }^{[15,24]}$ In our study, we observed that the SOD activity of the lung tissue increased after lower limb $\mathrm{I} / \mathrm{R}$ and decreased when amantadine was applied. We believe that the reduction in the SOD activity may be related to the amantadine administration.

Free oxygen radicals that formed in $I / R$ injury initiate lipid peroxidation by attacking lipids in membranes due to their high activity. The radicals cause cellular injury by oxidizing membrane lipids, cellular proteins and deoxyribonucleic acid. The MDA is considered as an indicator of lipid peroxidation mediated by free oxygen radicals. ${ }^{[30]}$ Previous studies showed that MDA levels increased after $I / R$ injury and decreased by antioxidant agent application. ${ }^{[24,31-33]}$ Similar to these studies, we observed that MDA levels of the lung tissue increased after I/R. In addition, we found that MDA levels decreased, when we administered amantadine before $\mathrm{I} / \mathrm{R}$. This decrease in MDA level suggests that amantadine may have protective effects in I/R.

In the underlying cause of lung injury following lower limb I/R injury, the development of neutrophil sequestration by the inflammatory mediators stimulated by ischemic tissue and the accumulation of activated neutrophils into the lung through the bloodstream and accumulating in the pulmonary bed play an important role. Degranulation of the sequestered neutrophils leads to injury to the lung tissue. ${ }^{[34-36]}$ Injury of the lung is histopathologically manifested by alveolar wall thickening, interstitial edema, neutrophils, and infiltration of lymphocytes. ${ }^{[33]}$ It has been reported that the histopathological changes in the lung tissue due to $I / R$ injury of lower limb can be significantly reduced with various agents. ${ }^{[33,37,38]}$ In our study, neutrophil/lymphocyte and alveolar wall thickening scores were significantly increased after I/R. Although not statistically significant, there was a reduction in the alveolar wall thickening due to I/R injury through amantadine administration.

The main limitation of our study is its relatively small sample size; however, the Animal Research Committee allowed up to six rats per group per protocol.

In conclusion, amantadine as an NMDA antagonist with its neuroprotective effects may have a protective effect against $\mathrm{I} / \mathrm{R}$ injury, similar to other NMDA 
antagonists. Based on our study results, the lung tissue can be affected histopathologically by $I / R$ injury and this injury can be reversed by amantadine administration.

\section{Declaration of conflicting interests}

The authors declared no conflicts of interest with respect to the authorship and/or publication of this article.

\section{Funding}

The authors received no financial support for the research and/or authorship of this article.

\section{REFERENCES}

1. Jennings RB, Reimer KA. The cell biology of acute myocardial ischemia. Annu Rev Med 1991;42:225-46.

2. Zimmerman BJ, Granger DN. Reperfusion injury. Surg Clin North Am 1992;72:65-83.

3. Dammers R, Wehrens XH, oude Egbrink MG, Slaaf DW, Kurvers HA, Ramsay G. Microcirculatory effects of experimental acute limb ischaemia-reperfusion. Br J Surg 2001;88:816-24.

4. Khalil AA, Aziz FA, Hall JC. Reperfusion injury. Plast Reconstr Surg 2006;117:1024-33.

5. Takito AM, Silva JCCB , Bueno V, Franco M, Burihan E. Ischemic and reperfusion syndrome of hind limbs: functional and histological renal changes in rats. Medicina (Ribeirão Preto) 2005;38:294-300.

6. Duru S, Koca U, Oztekin S, Olguner C, Kar A, Coker C, et al. Antithrombin III pretreatment reduces neutrophil recruitment into the lung and skeletal muscle tissues in the rat model of bilateral lower limb ischemia and reperfusion: a pilot study. Acta Anaesthesiol Scand 2005;49:1142-8.

7. Fantini GA, Conte MS. Pulmonary failure following lower torso ischemia: clinical evidence for a remote effect of reperfusion injury. Am Surg 1995;61:316-9.

8. İşbir S, Akgün S, Ak K, Civelek A, Tekeli A, Çobanoğlu A, et al. Effect of acute lower limb ischemia/reperfusion injury on the free oxygen radical systems in lungs. Turk Gogus Kalp Dama 2000;8:632-4.

9. Baltalarli A, Önem G, Gökşin İ, Rendeci O, Saçar M, Çolakoğlu N. Ischemic preconditioning increases the lung injury caused by ischemia. Turk Gogus Kalp Dama 2000;8:537-40.

10. Danysz W, Parsons CG, Kornhuber J, Schmidt WJ, Quack G. Aminoadamantanes as NMDA receptor antagonists and antiparkinsonian agents--preclinical studies. Neurosci Biobehav Rev 1997;21:455-68.

11. Farnebo LO, Fuxe K, Goldstein M, Hamberger B, Ungerstedt U. Dopamine and noradrenaline releasing action of amantadine in the central and peripheral nervous system: a possible mode of action in Parkinson's disease. Eur $\mathbf{J}$ Pharmacol 1971;16:27-38.

12. Cámara-Lemarroy CR, Guzmán-de la Garza FJ, AlarcónGalván G, Cordero-Pérez P, Fernández-Garza NE. The effects of NMDA receptor antagonists over intestinal ischemia/ reperfusion injury in rats. Eur J Pharmacol 2009;621:78-85.
13. Özdemir HH, Demir CF, Berilgen MS, Akgün B, Kuloğlu T, Kapan O, et al. Protective effects of memantine induced by cerebral ischemia and reperfusion injury in rats. Turk $\mathbf{J}$ Neurol 2013;19:85-9.

14. Ozsüer H, Görgülü A, Kiriş T, Cobanoğlu S. The effects of memantine on lipid peroxidation following closed-head trauma in rats. Neurosurg Rev 2005;28:143-7.

15. Kirisci M, Oktar GL, Ozogul C, Oyar EO, Akyol SN, Demirtas CY, et al. Effects of adrenomedullin and vascular endothelial growth factor on ischemia/reperfusion injury in skeletal muscle in rats. J Surg Res 2013;185:56-63.

16. Koksel O, Yildirim C, Cinel L, Tamer L, Ozdulger A, Bastürk M, et al. Inhibition of poly(ADP-ribose) polymerase attenuates lung tissue damage after hind limb ischemiareperfusion in rats. Pharmacol Res 2005;51:453-62.

17. Yang CL, Chen CH, Tsai PS, Wang TY, Huang CJ. Protective effects of dexmedetomidine-ketamine combination against ventilator-induced lung injury in endotoxemia rats. J Surg Res 2011;167:e273-81.

18. Wang XD, Lu YL, Lai RC, Li YP, Huang W, Xu M. Protective effect of ketamine against acute rat lung injury induced by liopolysaccharide and its mechanism. Nan Fang Yi Ke Da Xue Xue Bao 2007;27:1848-50.

19. Xiao X, Zhang H, Wang H, Li Q, Zhang T. Neuroprotective effect of amantadine on corticosterone-induced abnormal glutamatergic synaptic transmission of CA3-CA1 pathway in rat's hippocampal slices. Synapse 2017;71.

20. Giacino JT, Whyte J, Bagiella E, Kalmar K, Childs N, Khademi A, et al. Placebo-controlled trial of amantadine for severe traumatic brain injury. N Engl J Med 2012;366:819-26.

21. Tan L, Ge H, Tang J, Fu C, Duanmu W, Chen Y, et al. Amantadine preserves dopamine level and attenuates depression-like behavior induced by traumatic brain injury in rats. Behav Brain Res 2015;279:274-82.

22. Atahan E, Ergün Y, Kurutaş EB, Alici T. Protective effect of zinc aspartate on long-term ischemia-reperfusion injury in rat skeletal muscle. Biol Trace Elem Res 2010;137:206-15.

23. Kiriş İ, Okutan H, Savaş Ç, Yönden Z, Delibaş N. Deneysel aortik iskemi-reperfüzyon modelinde renal hasara gadolinyum klorürün etkisi. Damar Cerrahisi Dergisi 2005;14:13-8.

24. Kapan Ş, Kiriş İ, Kılbaş A, Altuntaş İ, Karahan N, Okutan H. Eritropoietinin sıçan aortik iskemi-reperfüzyonunda akciğer hasarı üzerine etkisi. Turk Gogus Kalp Dama 2009;17:110-6.

25. Reiter RJ, Melchiorri D, Sewerynek E, Poeggeler B, BarlowWalden L, Chuang J, et al. A review of the evidence supporting melatonin's role as an antioxidant. J Pineal Res 1995; 18:1-11.

26. El-Sayyad SM, Soubh AA, Awad AS, El-Abhar HS. Mangiferin protects against intestinal ischemia/ reperfusion-induced liver injury: Involvement of PPAR- $\gamma$, GSK-3 $\beta$ and Wnt $/ \beta$-catenin pathway. Eur J Pharmacol 2017;809:80-6.

27. Cavdar Z, Ural C, Celik A, Arslan S, Terzioglu G, Ozbal S, et al. Protective effects of taurine against renal ischemia/ reperfusion injury in rats by inhibition of gelatinases, MMP-2 and MMP-9, and p38 mitogen-activated protein kinase signaling. Biotech Histochem 2017;92:524-35. 
28. Xia F, Xia Y, Chen S, Chen L, Zhu W, Chen Y, et al. Lipid emulsion mitigates impaired pulmonary function induced by $\operatorname{limb} \mathrm{I} / \mathrm{R}$ in rats through attenuation of local cellular injury and the subsequent systemic inflammatory response/ inflammation. BMC Anesthesiol 2017;17:83.

29. Zhang Y, Rong S, Feng Y, Zhao L, Hong J, Wang R, et al. Simvastatin attenuates renal ischemia/reperfusion injury from oxidative stress via targeting Nrf2/HO-1 pathway. Exp Ther Med 2017;14:4460-6.

30. Gutteridge JM. Lipid peroxidation and antioxidants as biomarkers of tissue damage. Clin Chem 1995;41:1819-28.

31. Uysal A, Burma O, Akar İ, Özsin Kaan K, Rahman A, Üstündağ B, et al. Protective effect of melatonin on lung injury caused by ischemia-reperfusion of the lower extremities. Turk Gogus Kalp Dama 2006;14:308-14.

32. Alaçam B, Ek RO, Yıldız Y, Serter M, Boylu NT, Temoçin $\mathrm{S}$. Abdominalaorta iskemi- reperfüzyonuna bağlı gelişen akciğer hasarında karnozinin etkisi. Adnan Menderes Üniversitesi Tıp Fakültesi Dergisi 2010;11:41-7.

33. Önem G, Saçar M, Aybek H, Kocamaz E, Adalı F, Saçkan Gökhan K, et al. Protective effects of cilostazol and levosimendan on lung injury induced by lower limb ischemia-reperfusion. Turk Gogus Kalp Dama 2012;20:577-83.

34. Pararajasingam R, Nicholson ML, Bell PR, Sayers RD. Noncardiogenic pulmonary oedema in vascular surgery. Eur $\mathrm{J}$ Vasc Endovasc Surg 1999;17:93-105.

35. Carden D, Xiao F, Moak C, Willis BH, Robinson-Jackson S, Alexander S. Neutrophil elastase promotes lung microvascular injury and proteolysis of endothelial cadherins. Am J Physiol 1998;275:H385-92.

36. Windsor AC, Mullen PG, Fowler AA, Sugerman HJ. Role of the neutrophil in adult respiratory distress syndrome. Br J Surg 1993;80:10-7.

37. Akahane HGK, Gomes RZ, Paludo KS, Linhares F, Lopes L. The influence of allopurinol and post-conditioning on lung injuries induced by lower-limb ischemia and reperfusion in Wistar rats. Acta Cir Bras 2017;32:746-54.

38. Küçükebe ÖB, Özzeybek D, Abdullayev R, Ustaoğlu A, Tekmen I, Küme T. Effect of dexmedetomidine on acute lung injury in experimental ischemia-reperfusion model. Braz $\mathbf{J}$ Anesthesiol 2017;67:139-46. 